\title{
The Old Church Slavonic Version of Epiphanius of Salamis' Panarion in the Ephraim Kormchaya (THE $12^{\mathrm{TH}}$ CENTURY)
}

$\mathrm{T}$ he Panarion, a treatise on heresies, belongs to the series of dogmatic and polemical works which resulted in the establishment of Epiphanius' deserved reputation as a diligent defender of the Orthodox faith, who was incardinated in the ancient formalist doctrine of Nice, and a "hunter of heresies". Appearing together with different passages in the first Old Church Slavonic text of the period of the already Christian empire of Simeon the Great, in a time of great social controversies, the treatise was rapidly spreading in the whole Orthodox-Slavic world, mostly due to its fervent defense of the simple faith.

It is not a coincidence that some chapters of this monumental work can be found in the last part of the code that contains the most ancient translation of the Syntagma in XIV Titles, known as Efremovskaya kormchaya. The most ancient code of Syntagma (Moscow, GIM, Sin 227) was copied by a scribe named Ephraim in Novgorod at the beginning of the $12^{\text {th }}$ century. Although it had been first concisely catalogued by Undol'skij ${ }^{1}$, its importance as a valuable document of Slavic patrimony was noticed by I.I. Sreznevskij, who carried out an analytical description of its content comparing it to two further copies, one of Solovetsky monastery and other of Svyato-Toitsky monastery². In 1906-1907 V.N. Beneshevich published a scientifically exemplary Slavonic edition with a parallel Greek text ${ }^{3}$. Inexplicably, however, the precious manuscript would remain out of the Slavists' interest for a long time. Thus, even today, it is becoming a subject of profound linguistic analysis and is receiving the attention it has always deserved. Some researchers, such

\footnotetext{
${ }^{1}$ В.М. Ундольский, Описание славянских рукописей Московской патриарией библиотеки, Москва 1867 [= ЧИОИДР, 2.3], p. 38-44.

${ }^{2}$ И.И. Срезневский, Обозрение древних русских списков Кормчей книги, Санкт-Петербург 1897 , p. $15-46$.

${ }^{3}$ Древнеславянская кормчая XIV титулов без толкований, vol. I.1-3, ed. В.Н. Бенешевич, Санкт-Петербург 1906-1907.
} 
as F.I. Buslaev and V. Jagić, used to assume the Bulgarian origins of the Syntagma's translation, while others, including A.S. Pavlov, A.I. Almazov, S.P. Obnorski, or R.G. Pikhoya supported the hypothesis of an Old Russian translation, carried out by Bulgarian intellectuals in the Kyevian Rus under the rule of prince Yaroslav the Wise (1015-1054). The hypothesis about the original East Slavonic translation is still supported by Russian scholars. Still unconvincing are claims by some of them that the presence of single primordial Russianisms in the text of the Kormchaya may indicate the existence of a translation in Russian, which is proved by the fact of introducing juridical East Slavic terms in places in which the Slavonic Ecclesiastical terminology was not sufficient to render the Greek language. Moreover, this assumption would tally with the historical realities, as apparently, in Bulgaria, there was no need for Slavonic canonical stories, since the Greek texts were used. On the other hand, Russia, after its conversion to Christianity, required codes of Ecclesiastical Law ${ }^{4}$.

It was only in the last decade that Russian Paleo-Slavist Kirill Maksimovich presented incontrvertible evidence of the Bulgarian Preslavian origins of the text: the first original translation might have been made at the Literary Centre of Preslav, in the first half of the $10^{\text {th }}$ century ${ }^{5}$. The scholar claims that the translation of the Byzantine Syntagma in XIV Titles should be linked to Bulgaria and he also admits the possibility of the successive editorial interventions in Old Russian, hence the presence of Russianisms in spelling and lexicon, including the "cokanie" typical of the Novgorod's dialect. Valid arguments that should be considered while hypothesizing about the localization of the translation include the numerous phonetic and lexical Bulgarianisms in the literary language and the dialect of Preslav, such as Б'ъХ'ъды 'all, totally', чиснл 'number', чиститель 'priest', чьваньць 'vase', цАтт 'small coin', forms without $l$-epenthetic, confusion between the nasals, traces of the Glagolitic script in the spelling, etc. Only in Bulgaria of Simeon the Great could the translator have correctly used complicated theological terms, such as съитавъ dition dating back to the translations of a Bulgarian, John the Exarch. All the elements of the language mentioned above, regionally marked, evidently point to the Bulgarian prototype.

\footnotetext{
${ }^{4}$ Cf. А.А. Турилов, Б.Н. Флоря, Христианская литература у славян в середине X - середине ХІ в. и межставянские культурные связи, [in:] Христианство в странах Восточной, Юго-Восточной и Центральной Европы на пороге второго тысячилетия, еd. Б.Н. Флоря, Москва 2002, p. 398-459, 407-409, 436-438; А.А. ПичХАДЗЕ, Переводческая деятельность в домонгольской Руси. Лингвистический аспект, Рукописные памятники Древней Руси, Москва 2011, p. 18-24. ${ }^{5}$ К.А. МАксимович, Древнерусская Ефремовская кормчая ХІІ в.: локализация перевода в связи с историей текста, [in:] Лингвистическое источниковедение и история русского языка, ed. А.М. МолДовАн, А.А. ПлетневА, Москва 2006, р. 102-113.
} 
In $2010 \mathrm{~K}$. Maksimovich and L. Burgman published a complete Greek-Slavic index based on the Kormchaya, one Greek-Slavonic and another Slavonic a tergo ${ }^{6}$. The index contains a total of 6,170 lexemes, out of which around 1,800 were not registered even in the authoritative dictionary of Prague. The index not only opens up a wide range of opportunities for researchers of translations of Slavonic literature and historians but also offers a useful instrumentum studiorum for the reception and fortunes of the Byzantine cultural patrimony in the Slavic territories.

The Old Church Slavonic version of the collection of heresies extracted from the dogmatic and polemical treatise, Epiphanius of Salamis' Panarion, was inserted precisely in the last part of the Kormchaya (ff. 249r-275v of the code; p. 644-706 of the Beneshevich edition). In the history of theology, Epiphanius occupies a position of prominence among the great heresiologists. He is at the end of a long heresiologic line, which was started in the $2^{\text {nd }}$ century by Justin Martyr, the author of the earliest Anti-Heretical Treatise, and continued by Irenaeus of Lugdunum (Adversus haereses) and Hippolytus of Rome (Syntagma Against Heresies). The subsequent heresiologists, such as Philastrius of Brescia, the author of Diversarum Haereseum Liber (called for brevity De Haeresibus), used his work as a model ${ }^{7}$. In the following centuries, different authors tended to insert in their works the lists, of different length, of heresies and schisms. The title of Panarion

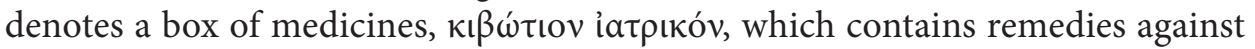
pangs and mortal stings, an antidote against the venom of the errors in the doctrine of faith. It can be seen as a monumental compendium of the former heresiologic literature and, at the same time, a precious container of documents and texts, not only heretical, abounding in citations of the works which survived only thanks to this source. We are dealing with a true "first-aid manual" created with the aim of the protection of Orthodoxy and as a very successful guide for the faithful, from the period of the first Old Slavonic texts.

The importance of Epiphanius's treatise against the heresies in the First Bulgarian Empire of Boris and Simeon is proved by the fact that some fragments of the treatise had already been inserted in the Miscellany of Sviatoslav/Simeon of 10738: f. 137a14-140a17: Gтаго Юпифана отть понарии; f. 167b22-167d5: GтТо Юпифанига от парии; f. 216с24-216d: Єпифаниюво ӧ понари.

As mentioned before, its notoriety is related to a list of eighty heresies, sects and schisms, described with a view to preventing their diffusion. Epiphanius insists on the number of eighty schisms, drawing his idea from the Song of Songs

\footnotetext{
${ }^{6} \mathrm{~K}$. Maksimovič, Das byzantinische Syntagma in 14 Titeln ohne Kommentare in altbulgarischer Übersetzung. Slavisch-griechisches, griechisch-slavisches und rückläufiges (slavisches) Wortregister, vol. I-II, Frankfurt am Main 2010 [= FBR, 27].

${ }^{7}$ Cf. B. Mondin, Storia della Teologia. Epoca patristica, vol. I, Bologna 1996, p. 319-324.

${ }^{8}$ Симеонов сборник (по Светославовия препис от 1073 г.), vol. I, Изследвания и текст, София 1991; vol. II, Речник-индекс, София 1993; vol. III, Грбцки извори, София 2015.
} 
$(6,8-9)$ and distinguishes from the only real Christ's Church - the "Queen" and

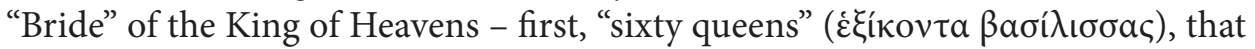
is sixty generations of men legitimate from Adam to Christ, who prepared His advent and the parousia of His Church, and, secondly, "eighty concubines" (oj $\gamma \delta$ -

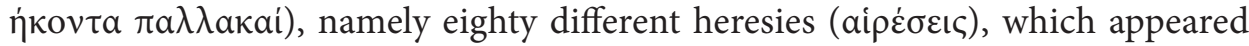
in the period of the queens of Christ before his Accession, or after it (Haeresis

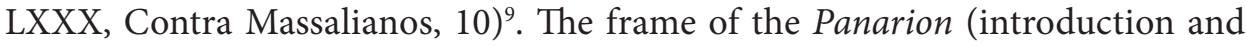
its end) identifies the eighty concubines from the Song in the heresies since they were not faithful to the conjugal unity with God. As the concubines are women " $\varphi \varepsilon \lambda \varepsilon \dot{\gamma} \varepsilon \sigma \theta \alpha$ ": women $(\varphi \varepsilon \lambda \varepsilon \dot{\gamma} \gamma)$ in half ("̋ $\sigma \theta \alpha)$, the heresies are also partially true, incomplete and, thus, deceptive (Expositio Fidei, 4) ${ }^{10}$.

The classification of the eighty heresies follows a rigorous order in three books, grouped in seven volumes of various dimensions, divided according to the chronological criterion. Also here an allusion to the Old Testament can be observed: Solomon was endowed with a proverbial sense of order and justice, which he introduced both in the administration of his house and the state. On the other hand, when he married the daughter of the Pharaoh, he had already had sixty queens and eighty concubines ${ }^{11}$. In this manner, Epiphanius presents twenty heresies that come from the period before the incarnation of Christ and another sixty from the Christian period. Among the eighty he also includes five PreChristian - Barbarism, the Scythians, Hellenism, Judaism, Samaritanism - which

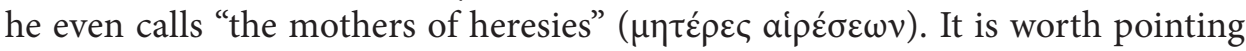
out that when the author talks about the Pre-Christian period, the concept of heresy is probably used in the neutral sense of the "religious state of humanity".

The First book of Panarion consists of three volumes and a total of forty-six heresies which include descriptions of the respective doctrines they share:

In the First book, there are twenty heresies listed, all prior to the incarnation of Christ, starting from the five so-called "mothers of heresies". The four heresies of Pythagoreans (also called Peripatetics), the Platonists, the Stoics, and the Epicureans were derived from Hellenism. Although among the Greeks the term heresy had at times a neutral meaning for all these spiritual currents (or philosophical schools), with Epiphanius, it started to acquire the sense of an inaccurate succession of the model of revealed righteous faith. Between the Judaic Law and the

\footnotetext{
${ }^{9}$ Epiphanius Constantiensis in Cypro Episcopus, Adversus Octoginta Haereses, Panarium, [in:] PG, vol. XLII, col. 1076-1077 (cetera: EpIPhanius Constantiensis, Adversus); Italian translation: Epifanio, Panarion, ed. G. PInI, vol. I, Brescia 2010; vol. II, Brescia 2012; vol. III, Brescia 2017. Complete translation in Russian: Творения святых отиев, Творения св. Епифания Кипрскаго, vol. XLII, pars 1, 1863; vol. XLIV, pars 2, 1864; pars 3, 1872; vol. XLVIII, pars 4, 1880; vol. V, pars 5, 1882.

${ }^{10}$ Epiphanius Constantiensis, Adversus, [in:] PG, vol. XLII, col. 1083-1084; Epifanio, L'Ancora della fede, trans., praef. et ed. C. Riggi, Roma 1993, p. 14.

${ }^{11}$ 3Reg 11, 3. Cf. A. Bianchi-Giovini, Sulla Storia Universale di Cesare Cantù, Milano 1846, p. 290.
} 
incarnation of Christ, eleven heresies were presented, out of which seven were Judaic (the Scribes, the Pharisees, the Sadducees, the Osseans, the Nazarenes, the Hemerobaptists, the Herodians), and four Samaritan (the Goroteni, the Sebuei, the Essenes, the Dositheni). Therefore, the number of those born after the Law of Judaism and Samaritanism stands at eleven. The total number of all the heresies created before the Incarnation, from Adam to the Advent, reaches twenty.

The polemic zeal of Epiphanius is concentrated, in reality, mostly on the heresies that appeared after the arrival of Christ, those which, although called

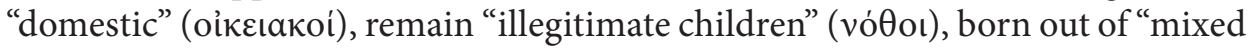

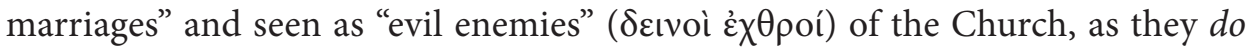
not belong to the real faith of the Apostles of the Lord. For Epiphanius, any Chris-

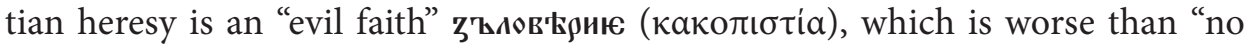

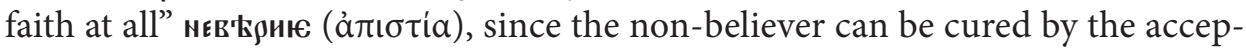
tance of the real faith. The z'ыловкрию, on the other hand, cannot be healed. The heresies lost the truth - the right path - by deviating "towards the right or left" of "the royal road", followed by the Church, and they wander in profound delusion without any particular destination (Haeresis LXIX, Contra Ariomanitas, 2) ${ }^{12}$.

Therefore, there are sixty heresies of the Christian period, from the incarnation of Christ to the Empire of Valens and Gratian, classified by Epiphanius as follows:

In the Second volume, there are thirteen Gnostic heresies, i.e. the Simonians, the Menanders, the Satornils, the Basilideans, the Nicolaitans, the Gnostics, (also called the Stratiotics or the Fibionites, by some called the Secundianits, by others the Socratians or the Zacchaei, and still by the others the Coddians or the Borborites) the Carpocrateans, the Cerinthians or Merinthians, the Nazarenes, the Ebionites, the Valentianists, the Secundians (joined by Epiphanius and Isidore), the Tolomeonits.

In the Third volume, there are another thirteen Gnostic heresies: the Marcosians, the Colorbasi, Heracleonites, the Ophites, the Cainites, the Sethians, the Archontics, the Cerdonians, the Marcionites, the Lucianists, the Apelleans, the Severities, the Tazianei (Tatiani), the Encratites.

The Second book consists of two vast volumes.

The First book contains eighteen heresies: the Montanists, the Phrygians or the Tascodrugites, the Pepuzians or the Priscillianists or the Quintilians, joined by the Artotyrites, the Quartodecimans (who celebrate the Pasch always on the same day of the year), the Alogians (who repudiate the Gospel and Apocalypse of John), the Adamites, the Sampsaens or Elcesaites, the Theodosians, the Melchizedezians, the Bardesanists, the Noetians, the Valesians, the Cathars (in Rome called the Montanists), the Angelics, the Apostles or the Apotactites, the Sabellians, the imprudent Origenists, the Origenists, disciples of Adamantius.

${ }^{12}$ Epiphanius Constantiensis, Adversus, [in:] PG, vol. XLII, col. 728. 
In the Second volume, there are four heresies of the followers of Paul of Samosata (the Paulicians), the Manicheans or the Acuanites, the Heraclites, the Milesians (the schismatics of Egypt), the Arians or the Ariomanits.

The Third book consists of two volumes.

In the First volume, there are seven heresies: the Audians (rather schismatic than real heretics), the Photinians, the Marcellians, the Semi-Arians, the Pneumatomachians, who blasphemed the Holy Spirit, the Aerians, the Aetians or the Anomoeans. Epiphanius refers with particular polemic zeal and attention to details of the doctrine of Antiochian deacon Aetius, who, together with his disciple Eunomius, had founded the extreme wing of the Arian party of the Anomoeans.

In the Second volume, there are four heresies: the Dimoerites, who did not fully acknowledge the humanity of Christ; the Apollinarians, who deny the virginity of Saint Mary (who after a generation united with Joseph), also called the Antidicomarianites, who, in Her name, celebrate the offer of rusk or kollira and, in consequence, are called the Collyridians, the Messalians (joined by the Martyrianites of Greek origins, the Euphemites, and the Satanians). The inventory of eighty heresies is completed with the doctrine of the Messalians, cited at the end.

The Panarion was composed by Epiphanius between 374 and 377. Over the following centuries, the biblical importance - the precise doctrinal sense - of the number of heresies was lost. In Byzantium, the abbreviated variants of the treatise were diffused. In time, other dogmatic-polemical texts were interpolated and, above all, various lists of heresies attributed to Epiphanius himself. Beneshevich identified four Greek codes, of which the Old Church Slavonic translation was made, representing three Greek editions: the principal Vallicell. F.47 of the $10^{\text {th }}$ century, two codes of Patmos (Patm. 172 and Patm. 173) of the $9^{\text {th }}$ century, and another Vallicell. F.10 of the $10^{\text {th }}$ century. The choice of the code Vallicel. F.47 would have been determined by the fact that the Old Church Slavonic version represents the synthesis of the lexicon of all the three Greek editions ${ }^{13}$. According to Maksimovich, it cannot be ruled out that it was the consequence of the collation of the Syntagma in XIV Titles performed in Bulgaria, based on Greek codes of different editions ${ }^{14}$. In this principal Greek code, the number of the heresies listed from the Greek text and translated from the Slavic text is 103.

In the Kormchaya of Ephraim, the treatise opens directly with the presentation

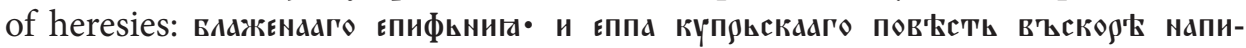

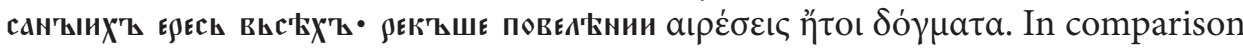
with the integral text of the Panarion, the more recent versions from which the Slavic version originates lack the following: a preface, synopsis at the beginning and at the end of every volume, and the final discourse which closes the treatise, entitled Discourse in defense of the right faith and truth, represented by the

\footnotetext{
${ }^{13}$ В.Н. БЕнЕшевич, Древнеславянская кормчая..., p. III-IV.

${ }^{14} \mathrm{~K}$. Maкsımovič, Das byzantinische Syntagma in 14 Titeln..., vol. I, p. XXIV.
} 
saint Church, Catholic and apostolic. In his text, Epiphanius synthesized the fundamental points of the Orthodox Catholic doctrine - the Trinity, the incarnation of Christ, the resurrection of the dead, the Final Judgement - and the institutional principles which govern the Church - the liturgy, reunions, fasting, celebrations, the life of the believers and of the monks, the prescriptions of everyday life. Despite its synthetic character - or perhaps by its virtue - the Panarion remains the most complete treatise on heresies which the Fathers' era produced. General form in which every heresy is described usually comprises four parts: a short notice on the relation of the heresy with the already mentioned ones, followed by a brief presentation of common beliefs; a broader and detailed confutation of the respective doctrine, including arguments taken from the Scriptures and reductio ad absurdum of their beliefs; a comparison of the heresy with a repugnant animal, in the majority of cases a snake.

After the detailed description of the eightieth doctrine of the Massalians in the text of the Kormchaya, there is a long chapter inserted taken from their

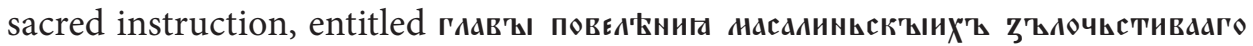

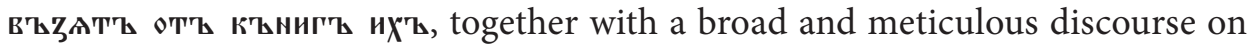
the refutation of their doctrine and behaviours, from f. 260v to f. 263r (p. 671-676 of Beneshevich).

It would be appropriate to ask why the Byzantine compilers showed such great interest in the doctrine and behaviour of the Messalians. One possible explanation could be that the followers of the neo-Messalian ideas still survived in the Balkan Peninsula at the time when the Greek codes were written. The continuity between the old and the new Messalians may have been a consequence of the deportations, in the $10^{\text {th }}$ and $11^{\text {th }}$ centuries, of the Anatolian populations to Thrace and some Messalians to Macedonia ${ }^{15}$.

The presentation of the teaching of the heresy, shared by the Messalian priests, continues from $\mathrm{f}$. $263 \mathrm{r}$ to f. $264 \mathrm{r}$, together with an additional fragment derived from the writings of Theodoret, which was identified with precision: it corresponds to the whole chapter X of the IV Book of The Ecclesiastical History of Theodoret. Theodoret, the bishop of Cyrrhus in Syria, was a literary master of the Antiochene party and a tireless defender of the most Orthodox expression of faith. This prolific writer lived in the turbulent decades of the Third and the Fourth ecumenical councils, in Efez (431) and Chalcedon (451), during which many important doctrinal issues (including the principal Christological dogmas) were discussed with quite a few consequences. As the protector of the Antiochene tradition and the opponent of Cyril, the powerful patriarch of Alexandria, Theodoret left a fascinating legacy. His biography demonstrates that he actively

\footnotetext{
${ }^{15}$ Some testimonies of the vitality and propagation of the heresy in the historical sources, in I. DujČEv, I bogomili nei paesi slavi e la loro storia, [in:] Medioevo bizantino-slavo, vol. I, Saggi di storia politica e culturale, Roma 1965, p. 251-282, 265sqq.
} 
participated in the heated dogmatic and politico-ecclesiastical fights of the $5^{\text {th }}$ century. Much as he shared the Nestorian dualism, in the theological debate, he represented its moderate trend. He composed his Ecclesiastical History of apologetic and polemical inspiration, in five books, between 444 and 449, eighty years after Epiphanius' Panarion ${ }^{16}$.

Theodoret was a well-known writer among the Bulgarian intellectuals already at the beginning of the $10^{\text {th }}$ or maybe even at the end of the $9^{\text {th }}$ century. In the First Bulgarian Empire, the Christian missionaries had to deal with various religious movements, in a state where there was no unity of faith. Slavic paganism was opposed by the paganism of the Proto-Bulgarians, while among the reprepresentatives of the most ancient population of the Balkanic territories traces of Gnosticism and other similar movements had survived. In this complicated historical reality, in which heretical movements were growing, Theodoret was one of the most frequently translated authors. For instance, in the translation of the work of John the Exarch An Exact Exposition of the Orthodox Faith (in the Old Church Slavonic tradition known as Theology or Heavens), John the Exarch includes at the end of chapter 49 ( $\boldsymbol{w} \mathbf{B} \mathbf{\mathrm { k }} \rho \mathbf{\mathrm { k }}$ ) the preface About Faith to the apologetic work by Theodoret of Cyrrhus A Cure of Greek Maladies (Graecorum affectionum curatio). In Preslav, A Compendium of Heretical Mythification (Haereticarum fabu-

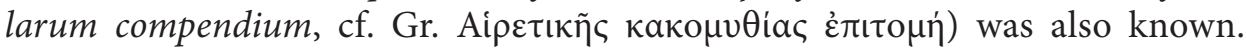
In the compilation of Hexaemeron, based on the writings of Basil the Great and Severian of Gabala, the Bulgarian writer again turned to Theodoret, using in the prologue to his work long fragments of the same composition. In the Miscellany of Sviatoslav/Simeon from 1073, there are twelve fragments of Theodoret's various writings. Some scholars claim that the heresy of Messalians is, in part, at the foundation of the Bogomilist sect, well known during the period of decadence of the Greek empire ${ }^{17}$. The Byzantine priests, among whom the heresy was also sometimes popular, contributed to the influence of the Messalian ideology on the Bogomils ${ }^{18}$.

After Theodoret's fragment in the part added to the list of heresies, the germs of three heresies are revealed (81, 82 and 83), and dissimulated in the doctrines of the Nestorians, the Eutychians, and the schismatic Monophysitists. In the

\footnotetext{
${ }^{16}$ Cf. the edition of Theodoretus Cyrensis, Historia ecclesiastica, [in:] PG, vol. LXXXII, col. 881-1280, the English translation http://www.documentacatholicaomnia.eu/03d/0393-0457,_Theodoretus, _Historia_Ecclesiastica,_EN.pdf. The English translation of various writings of Theodoret in I. PÁsTORI-KupÁn, Theodoret of Cyrus, New York 1996 [= ECF].

${ }^{17}$ Cf. A. Rigo, Messalianismo = Bogomilismo. Un'equazione dell'eresiologia medievale bizantina, $\mathrm{OCP}$ 56,1990 , p. 53-82.

${ }^{18}$ Cf. D. Овоlensky, The Bogomils. A Study in Balkan Neo-Manichaeism, Cambridge 1948 [repr. New York 1978], cap. III; A. RIgo, Monaci esicasti e monaci bogomili. Le accuse di Messalianismo e Bogomilismo rivolte agli esicasti ed il problema dei rapporti tra Esicasmo e Bogomilismo, Firenze $1989[=\mathrm{OV}, 2]$.
} 
Old Church Slavonic version, the aforementioned part is always attributed to Epiphanius and indeed constitutes a continuation of his long list of heresies.

Speaking of the heresies of the Monophysitists and the schismatics of Egypt, the author engages in an aggressive and accusatory discourse against Severus, a Monophysistic theologian, the Patriarch of Antioch in the first half of the $6^{\text {th }}$ century, who had elaborated the theory of monoenergetism (incarnation as the only hypostasis), and against his supporter John Philoponus. From f. 265v to f. $270 \mathrm{v}$ (p. 682-695 of Beneshevich), there were three fragments added (one of chapter IV and two of chapter VII) from the work of Alexandrine philosopher John the Grammarian and Tritheit, called The Laborious. The Slavic translator gives the epithet $\Phi$ ı

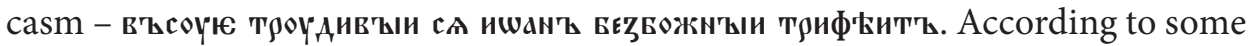
sources, it was John who had self-attributed the title of the Grammarian (Гран$\mu \alpha \tau(\kappa o ́ \varsigma)$, maybe because he taught grammar in Alexandria, but his opponents called him Tritheit, as he founded the sect of Tritheism. He was, in all probability, the most influential Byzantine philosopher in non-theological area, but also both an authoritative and controversial theologist. He belonged to Severus' and Non-Chalcedonian group, and in the $6^{\text {th }}$ century, he was the principal theorist of Tritheism, one of the three biggest trinitarian doctrines, in which God expresses himself in three non-consubstantial persons related to the divine triad, being in practice not the triune God, but three different divine Persons.

John Philoponus remained faithful to the Aristotelian concept and his work

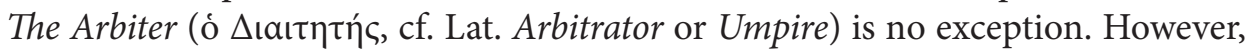
its Slavonic version, called Законьник'ъ, attributes to it a Christology of rather Monophysitic nature - with the consequent difficulties in the reconciliation of the original structure of the work with the Neoplatonist approach to the problem of the dualistic nature of Christ - to such an extent that his thesis moves into heretical positions, already condemned during the Council of Constantinople in 680-681. The Greek original of The Arbiter was lost and its text is preserved only in the Syriac version, published with an English translation ${ }^{19}$. The fragments cited in the Byzantine codes and interposed in the Slavonic version of the Kormchaya remain the unique testimonies of the authentic work of the Alexandrine writer.

The first text of John Philoponus taken from the Kormchaya comes from chapter IV of The Arbiter, and is entitled Законьник'ъ ó $\Delta$ เаıтпти́ 0 юстьств'

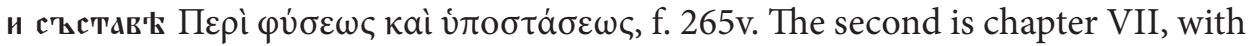
the presentation of the beliefs of Tritheism, f. $265 \mathrm{v}-269 \mathrm{v}$. The third is taken from the same chapter, f. $269 \mathrm{v}-270 \mathrm{v}$.

\footnotetext{
${ }^{19}$ Opuscula monophysitica Ioannis Philoponi, ed. A. ŠAndra, Beirut 1930. Cf.: L.S.B. MAcCoull, John Philoponus: Egyptian Exegete, Ecclesiastical Politician, [in:] Coptic Perspectives on Late Antiquity, Aldershot 1993, p. 211-220; B. LouRIÉ, John Philoponus, On the Bodily Resurrection, Scri 9, 2013, p. 79-88.
} 
It is followed by f. $270 \mathrm{v}-272 \mathrm{v}$ (p. 695-699 of Beneshevich) with the description of the heretical sects 84-98 up to emperor Heraclius (575-641).

From f. $272 \mathrm{v}$ to f. $274 \mathrm{v}$, the list of the heresies of the Empire of Heraclius continues up to more recent times "as it was written later". These are (99-101) the Monothelites, the Ethicoproscoptes, and the Hagareans, called Ishmaelites or Saracens.

The list concludes with the last two heretical sects mentioned in f. $274 \mathrm{v}$ to f. 275v, namely the Iconoclasts or Timoleons and the Aposchists, the description of which was taken from the writings of Nicephorus I (758-828), the patriarch of Constantinople (806-815) and an active opponent of Iconoclasm. Numbers 102-103 are recorded only in the Greek text and are missing in the Slavonic version.

Thus, the number of heresies registered by Epiphanius reaches 103. As more than a third were indicated under two or even more names, the total number is 140 different denominations.

At this point, I have undertaken a preliminary study of the lexicon of the Panarion and other treatises against heresies, in which 140 terms appearing in various heresies are considered, using two different approaches: grammatical and semantic. On that basis, 15 ethnonyms and eponyms, 60 terms of anthroponymic character formed on the basis of the names of heresiarchs and derived adjectives, 30 calques from Greek, and 35 compounded terms were identified.

It should be said by way of introduction that the Old Church Slavonic translation of the Kormchaya of Ephraim, although homogeneous only at intervals, stands out for its extreme literarism ${ }^{20}$. The diligence in transmitting Greek terms with precision at any cost leads to a huge number of unjustified semantic calques and the result is a text lacking in coherence between the parts of the same sentence.

The ethnonyms are related to different tribes and communities which inhabited the ancient and medieval worlds. Some of the 15 ethnic groups mentioned go back to the biblical period and some are contemporary with Epiphanius. It is worth noting that the Greek $\varepsilon$ évo was rendered as поган'ыи and'E $\theta v$ ó $\varphi \rho \omega v$ with поганом'ысльн'ыи.

There are duplicates of some of the ethnonym forms: one word follows the Greek original, while the other is a solution chosen by the translator or editor. There are three ethnonyms for the ancient Jewish people - the most frequent one

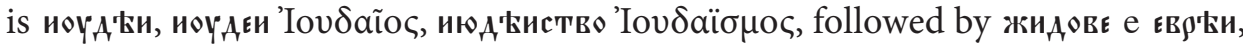
єврєи є̇ $\beta$ paíol. The $101^{\text {st }}$ heresy was founded by Hagareans, descendants of Hagar, the concubine of Abraham, with the clarification that they are called Ishmaelites or Saracens, after Sarah, the legitimate wife of Abraham: агьялньхтъ. Ижє изнаи-

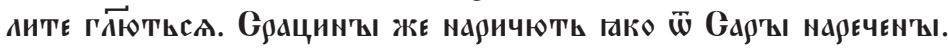

\footnotetext{
${ }^{20}$ The literalism is the most characteristic feature of the entire Slavonic text of the Kormchaya, cf. А.А. ПичхадзЕ, Переводческая деятельность в домонгольской Руси..., р. 23-24.
} 
Nearly half of the terms denominating heresies are non-translated Grecisms: nouns and adjectives, anthroponyms derived mostly from the names of heresiarch founders of different sects of identical names. I would like to cite some particular cases of the anthroponyms which instead were translated into Slavonic since they indicated the foreign terms unknown to the translator.

A noteworthy example is the heresy of the Carpocratians, a Gnostic school founded by Carpocrates of Alexandria, Neoplatonic philosopher and Egyptian preacher of the Greek language, who wanted to unite Christianity with Pagan philosophy, and who is known thanks to the writings of Irenaeus ${ }^{21}$. Carpocrates believed that every man, through metempsychosis, can have the powers of Jesus. Once this stage is reached, the soul can liberate itself from the oppression of rebirths, and again climb up the seven heavens dominated by the demons which created the world, in order to reach the Father. In the Slavonic text, Car-

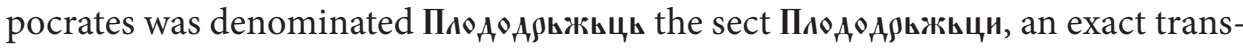
lation of two parts of the compound and a perfect calque from Greek.

The sect of the Cerdonians, founded by Cerdo of Eraclea, probably also unknown to the translator, was rendered literally with the calque as Прновр๘тьници, while the name of the heresiarch is Ктььдонты. Cerdo was a follower of Simon Magus and moved from Syria to Rome in the times of bishop Hyginus. He preached two opposite principles: he claimed that Christ was not born and, thus, because of not having the real body, his crucifixion was unreal. He also rejected the resurrection of the dead and the Old Testament ${ }^{22}$.

The Acuanites, the Palestinian heretics, appeared in the $3^{\text {rd }}$ century. They were the followers of Acuas, a disciple of Manete of Persia, and they shared the doctrine of the Manicheans. The name "Acuanites" is simply derived from the proper name Acuas, their founder, a veteran who arrived from Mesopotamia and Eleutheropolis in the times of Aurelian's Empire. According to their creed, there were two divine princes: one was the creator of Good and was called "Light", and the other created Evil and used the name of "Darkness". The Acuanites worshipped the moon and the stars, prayed to demons, disavowed the Testaments, and claimed that Christ appeared as a phantom and his death was fictional ${ }^{23}$. Ignoring their doctrine and the name of their founder, the Slavonic translator renders the term

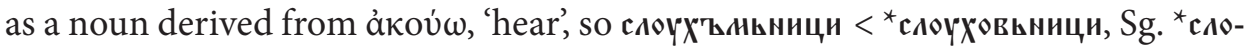
үховьник' 'hearing'.

In order to adapt a complex terminology, it was preferred to annotate, in various cases, the lexemes of oriental or Greek origins and, in this process, the Slavonic

${ }^{21}$ N.S. Bergier, Dizionario enciclopedico della teologia, della storia della Chiesa, degli autori che hanno scritto intorno alla religione, dei concilii, eresie, ordini religiosi ecc., vol. II, Venezia 1828, p. 62-63.

${ }^{22}$ Ibidem, p. 146.

${ }^{23}$ G. Moroni, Dizionario di erudizione storico-ecclesiastica da S. Pietro sino ai nostri giorni, vol. XLI, Venezia 1846, p. 120. 
version nearly always follows the Greek text. It is one of the techniques of adjustment of the text originating from a Bulgarophone environment, through interpretative supplements (glosses). In the explanation of the Greek term, the translation is usually free as a rule. In this regard, see the following examples: the Pythagoreans are called Peripatetics пифагорганє ९єкшє Ходильници ПиӨаүорккоі

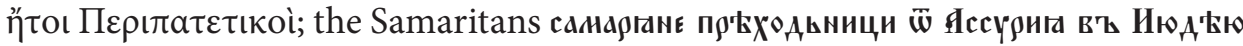

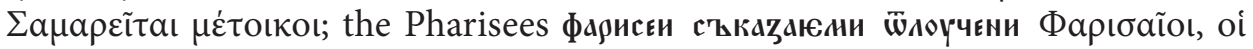
$\dot{\varepsilon} \rho \mu \eta v \varepsilon v o$ óvol à $\varphi \omega \rho ı \mu \dot{\varepsilon} v o l$; the Sadducees, the name is related to the Hebraic verbal form Sadaq, which means 'be right' садоүкєи съказаєаи правьдьни-

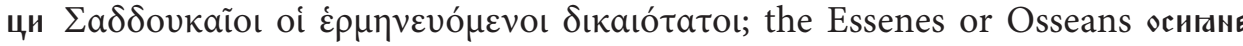

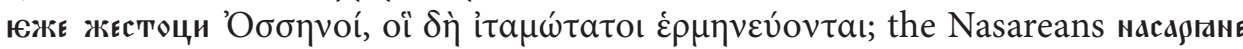

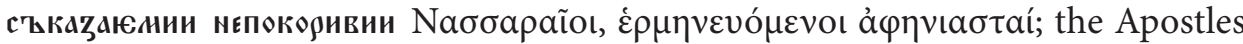

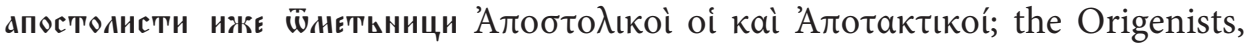
who take their name after Origen, commit nefarious acts and give up their bodies to corruption, doing the unspeakable things, and, thus, are also called ceasis-

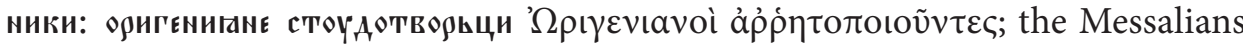
(or Messalians, in Aramaic měssalin 'prayerful'), an ascetic Christian movement from Asia Minor, deriving from the Martirianites of the Greek origin, as well as the Euphemians and the Satanions: несалитанє иже съкабањяи нолиттьници...

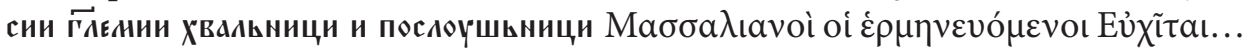
oi $\lambda \varepsilon \gamma o ́ \mu \varepsilon v o$ Eủ

In Epiphanius' text, there are twelve calques of the names of heresies which were not glossed, being the most widespread and well-known in the Christian world. In some cases, the translators - or the editors - most likely went after an expressive effect, and were thus driven by a rather precise stylistic intention.

There are four different Greek names of heresies which were rendered under the same lexeme Разоүньници: the Gnostics, Гvшбтікоí; the Noetians, the fol-

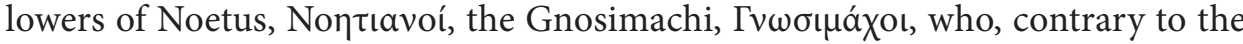
Gnostics, did not love works of science, reflection or meditation; the Agnoetae, the followers of the Christological doctrine of Alexandrian monophysite deacon Themistius (the $6^{\text {th }}$ century, from Gr. à $\gamma v \omega \eta$ in $\varsigma$, "one who does not know"), heretics who did not accept the omniscience of Christ as a $\operatorname{man}^{24}$, Нєразоүньници ижє

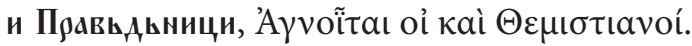

Other calques of Greek terms expressed with simple lexemes are: the Scribes,

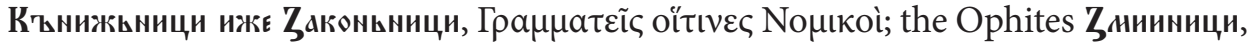

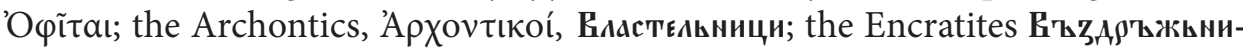
ци, Възарьжателе, 'Еүкратітаl; the Alogi, who rejected the the Gospel of John

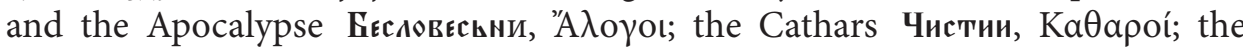
Apollinarists, whose creed was based on the notion that the humanity of Christ

${ }^{24}$ A. Vacant, Dictionnaire de Théologie Catholique, vol. I, Paris 1909, p. 585-596. 
was not total; the Diatomites, mentioned by John of Damascus, who considered

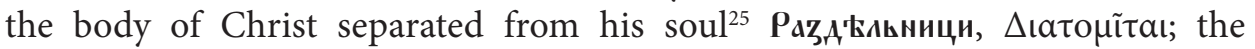

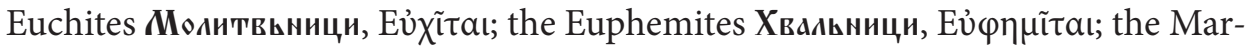
tirians Послоүшьници, Мартьрıаvo'; the Ichetes (Icetes) Мольвьници, 'Ікєтаі̃ol.

When it comes to the compound lexemes in the text of the Kormchaya of Ephraim, it should be noted that the only pertinent study undertaken to date was published in 1966 by Russian paleoslavist L. Vyalkina ${ }^{26}$. She found $430 \mathrm{com}$ pounds used 1,050 times during the work on the Beneshevich edition. In my study on the Panarion, I have discovered that missing from Vjalkina's list of compounds

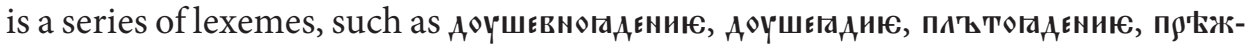
деварєнию, вдагочинению. Nowadays, with resources such as the complete Wortregister of Maksimovich and Burgman, a list of the compounds can be specified in greater detail. Another, more generic study on the formation and the stylistic function of the compounds in the Old Russian texts from the $12^{\text {th }}$ century was undertaken by S. Averina ${ }^{27}$. Two groups of compounds can be identified there: one is structural calques with exact correspondence to the Greek model, while the rest is formally independent from the corresponding Greek formations. One cannot avoid the impression that the translator searched for a major formal parallelism to the Greek text. It follows that the compounds were created for stylistic reasons, and as a result of a specific and clearly detectable technique of translation used in the Slavonic text.

Богодавьци,

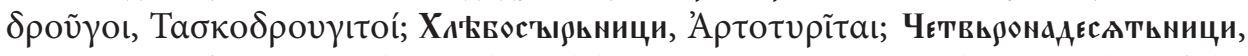

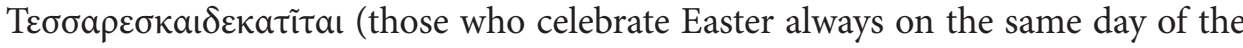

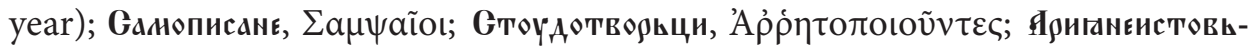

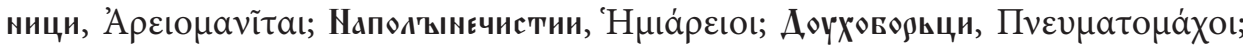

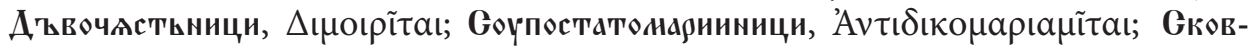

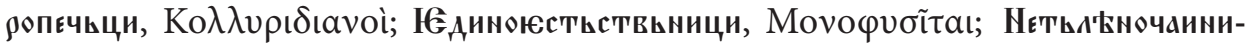

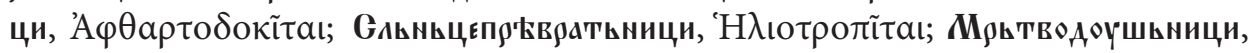

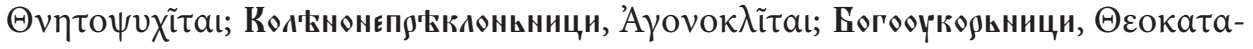
$\gamma \nu \tilde{\omega} \sigma \tau \alpha ;$ Х

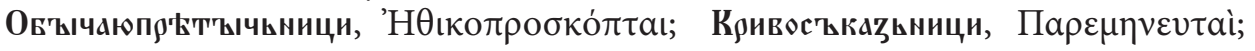

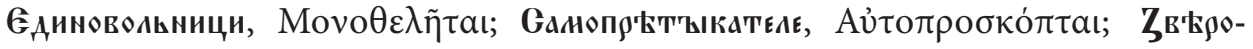

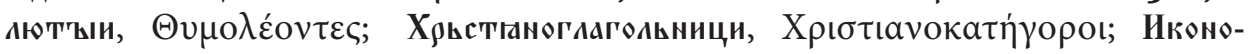

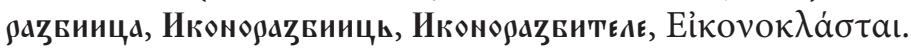

\footnotetext{
${ }^{25}$ Supplemento al Dizionario Tecnico-Etimologico-Filologico, ed. M.A. Marchi, Milano 1841, p. 78. 26 Л.В. Вялкина, Сложные слова в древнерусском языке в их отночении к языку греческого оригинала (на материале Ефремовской кормчей), [in:] Исследования по исторической тексикологии древнерусского языка, Москва 1964, р. 94-118.

${ }^{27}$ С.А. Аверина, Сложные слова в явыке ХІІ в., [in:] Древнерусский язык домонгольской поры. Межвузовский сборник, еd. В.В. Колесов, Ленинград 1991, р. 163-173.
} 
The evidence of assimilation, or rather adjustment, of some of the complex Greek models is the rendition, in the Slavonic translation, of simple Greek lexemes in the form of compounds.

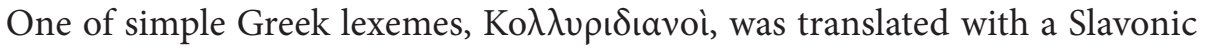
compound Сковропєчьци, Оковрадопєчьци, which was in turn translated as "those who in the name of Mary offered the sacrament of Eucharist in the form of rusk

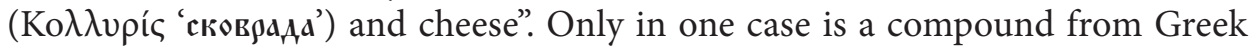

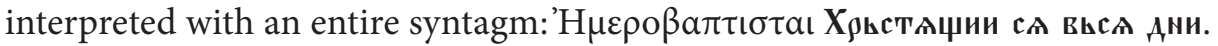

The compounds with the first component casto- translate Gr. av่to-, while

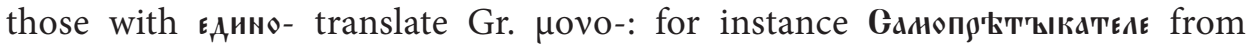

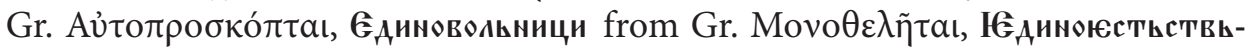
ници from Gr. ноvофибітаı.

Words with the negative particle нє- Нєразоүньници, Нєпокорив'ыи and with the preposition Бєс-/БєZ- Весловєсьни are not considered compounds.

An example of a compound semantic calque is the term нєтьл'Вньночаиници from Gr. 'А $\varphi$ of which was a continuation of monophysitism and appeared around the year 365. Its propagator, monophysite bishop Julian of Halicarnassus (beginning of the $6^{\text {th }}$ century) claimed that the body of Christ, incorruptible and unperturbed, could not have been subject to death and decay. The heresy affirmed aphartism - the idea that the body of Christ is incorruptible despite the Incarnation - and

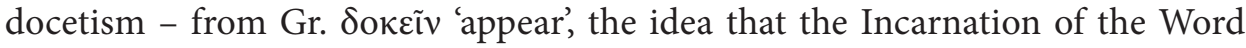
was only apparent since it was impossible for God to assume a material and corruptible body. His followers, through hunger, thirst, and sacrifice, wanted to participate in the passion of Christ ${ }^{28}$. This heresy may have been known in the Bulgarian environment, thanks to the Greek sources. The Boril's Synodikon of Orthodoxy, in the $13^{\text {th }}$ century, directs its anathemas also against these (Ижє $\overrightarrow{\mathrm{cNa}}$

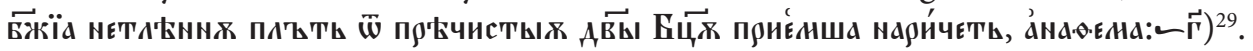
Two centuries later, also in the Constantine Manasses Chronicle, in the episode in which the last Roman emperor Justinian inclined toward the doctrine of the Aphtartodocets, they are described with a gloss, intended to explain their doc-

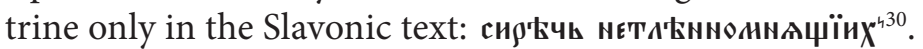

An original and particularly interesting performance on the interpretation of the Greek terms formed with the use of Slavic compounds is the description of the $53^{\text {rd }}$ heresy of the Sampsaens, the Judaizing Gnostics, also referred to as Elcesaites or Elkasaites, who lived in Arabia, in the vicinity of Palestine, across

${ }^{28}$ Dizionario delle origini, invenzioni e scoperte nelle arti, nelle scienze, nel commercio, nell'agricoltura ecc., Milano 1831, p. 1055.

${ }^{29}$ И. Божилов, А. ТотомановА, И. Билярски, Борилов синодик. Издание и превод, София 2010, $23 \mathrm{v}, 11-13, \S 84$.

${ }^{30}$ В. Велинова, Среднобългарският превод на Хрониката на Константин Манасий и неговият литературен контекст, София 2013, p. 159-160. 
the Dead Sea, and were deceived by the ideas of false prophet Elksai ${ }^{31}$, during the reign of emperor Trajan (98-117). Despite his Jewish origin, Elkhasai did not follow the Jewish Law, and his ideas constituted a syncretic combination of Hebrew and Christian elements combined with pagan-naturalistic components. Epiph-

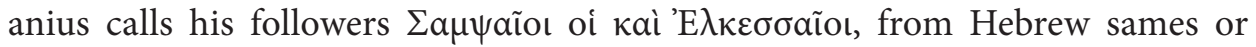
schemech 'the sun', as they believed that the prayer should follow the course of the sun from the east to the west. In the Slavic text, it is rendered in an expressive way, by defining Elkhasai's followers саниписанє. It can be presumed that the translator did not know the term and resorted to the interpretation from the popular etymology in order to adapt the Greek term. Nevertheless, since the description of the $30^{\text {th }}$ sect of the Ebionite community attests also the derived adjective

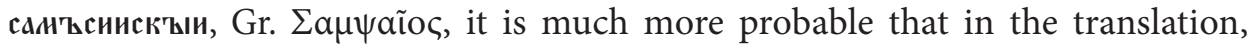
the Greek term is a transliteration (cf. another transliterated word сам'ьпсихии,

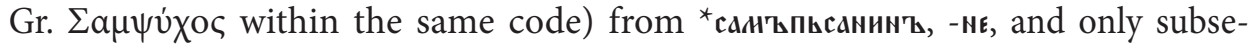
quently called for redaction or reconsideration. Another argument for assuming that the form of санописанє was not in the original translation, but appeared at a later stage, is that in our text, in most cases, the first component aujto- of the Greek compounds is translated in Old Church Slavonic with casto-. It should not be ruled out that the subsequent editors of the Panarion knew the Gnostic doctrine and tried to describe its essence more adequately. The Sampsaens, in fact, did not accept either Testament and preached that the nature of Christ was purely human. Christ would appear in the world as Adam, and then another time as a prophet. They rejected the existence of prophets and Christian apostles and, obviously, apostle Paul and all his writings. They described the Holy Spirit as a woman and based their doctrine on their own scriptures attributed to their founder, Elkhasai, hence the name of their sect, санописанє, "those who have (believe in) their scriptures".

A similar way of etymologizing the Greek terms in the Slavic linguistic environment can also be found in the name of the Barsanians, Barsanuphians or Semidulites, an Alexandrian and non-Chalcedonian separatist group, which separated itself from the Monophysitism. Since they rejected the holy communion

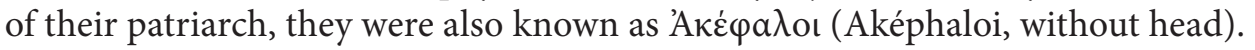
According to Timotheus I, the Patriarch of Constantinople, the Barsanuphians were probably named after their founder, the Bishop Barsanuphius, an Egyptian anchorite, a native of Palestine, who was nominated bishop anti-canonically. His nonconventional and unusual mysteries are described in detail in the article about the $86^{\text {th }}$ heresy. The Barsanuphians rejected the divine Eucharist and shared the errors of the Gaianites and the Theodosians, the followers of two rival Alexandrian patriarchs, Gaianas and Theodosius, concerning the admission of incorruptibility. They performed their sacraments with the use of the finest flour of ground grains, Gr. $\sigma \varepsilon \mu i \delta a \lambda ı \varsigma$ (simnel), brought by Dioscorus, touched with the fingertips

${ }^{31}$ N.S. Bergier, Dizionario enciclopedico della teologia ..., vol. II, p. 312-313. 
and put into their mouths as the sacrament of communion. As John of Damascus reports, they perceived the flour as sacred and venerated it as the most precious gift. Because of this particular characteristic, they were called the Semi-

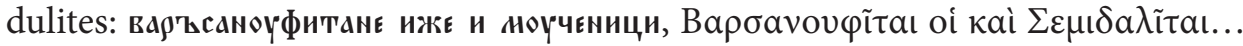

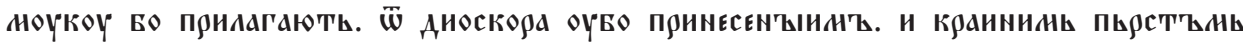
прикасаючесл ш̈коүшають моүкты. In all probability, in the original translation in Old Church Slavonic, the word жжчьници is derived from noun нжка 'flour', Gr. $\sum \varepsilon \mu i \delta a \lambda$ ıs with the suffix - ник'ъ. Ignoring the rite of heretical Semidulites, in the following writings, probably produced in the monasteries of Novgorod, the writer rewrote the form аs ногчемици 'martyrs'.

A very significant element of the translation for the literary culture is a restitution of the term Tascodrugites in Slavonic: Коловрьтьци. In reality, this was all about the Montanist heretics, who appeared in Phrygia in the late $2^{\text {nd }}$ century. They superstitiously carried a little cane and put a finger on the nose and mouth during their prayers in order to impose silence on their spectators. They were called the Tascodrugites - from the Phrygian words tascos 'cane' and druque 'nose.' The Greeks gave them the name of Patalovinchites and the Latins of Passilanosones, which had the same meaning. In the Panarion, Epiphanius describes their doctrine as follows: they accept two Testaments, and they believe in other prophets - Montanus and goddess Prisca. However, the Slavonic term demonstrates more profound knowledge of their spiritual rites, of which no mention is made in the treatise: thrown in a frenzy in the guise of Bacchus followers, they danced in their temple around a barrel, pretending that it was full of mystic wine ${ }^{32}$. It can be hypothesized that the translator had some information about their doctrine taken from the Byzantine sources. It is because of those particular ritual dances that the Slavonic intellectual calls them Коловрьтьци, 'those who dance in the circle'.

A large number of compounds influences the style of the entire composition and complicated syntactic structure of the text. The compounds turn out to be formed from nouns and adjectives, verbs and adverbs, and they certainly increase the expressiveness of the discourse. We can notice an intent of the translator to

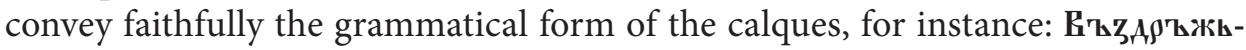
ници, Въздрьжателе, 'Еүкратіта for the noun Encratites, but for the participle

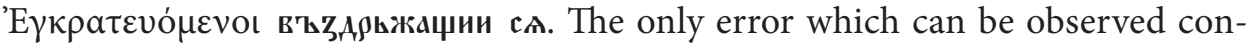
cerns the term 'schismatic' referringto the Egyptians: Gү̆пьтиганє иже и оБразьни-

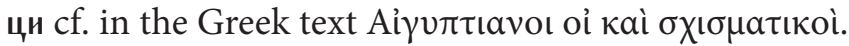

A preliminary lexicological study of the Old Church Slavonic text of Epiphanius and his other two texts reveals a formation of their translators in the context of a clearly Bulgarian tradition of Simeonian period. Within the limits of the canons imposed by the code of the (polemical) religious literature of the time,

\footnotetext{
${ }^{32}$ C.-L. RICHARD, Biblioteca sacra ovvero Dizionario universale delle scienze ecclesiastiche, vol. XVIII,
} Milano 1837, p. 399. 
the Slavonic version demonstrated a conspicuously autonomous character. It provides precious information about its literary as well as religious mentality and techniques of translation, thanks to the efforts made by the translator (or editor) in order to make the complicated and often unknown Byzantine dogmatic terminology accessible to the Bulgarian public.

\section{Bibliography}

\section{Primary Sources}

Bergier N.S., Dizionario enciclopedico della teologia, della storia della Chiesa, degli autori che hanno scritto intorno alla religione, dei concilii, eresie, ordini religiosi ecc., vol. II, Venezia 1828.

Bozhilov I., Tотомanova A., Biljarski I., Borilov sinodik. Izdanie i prevod, Sofia 2010.

Dizionario delle origini, invenzioni e scoperte nelle arti, nelle scienze, nel commercio, nell' agricoltura ecc., Milano 1831.

Drevne-slavyanskaya Kormchaya XIV titulov bez tolkovany, vol. I.1-3, ed. V.N. Beneshevich, Sankt-Peterburg 1906-1907.

Epifanio, L'Ancora della fede, trans., praef. et ed. C. Riggi, Roma 1993.

Epifanio, Panarion, ed. G. Pini, vol. I, Brescia 2010; vol. II, Brescia 2012; vol. III, Brescia 2017.

Epiphanius Constantiensis in Cypro Episcopus, Adversus Octoginta Haereses, Panarium, [in:] Patrologiae cursus completus, Series graeca, vol. XLII, ed. J.-P. Migne, Paris 1863.

Maкsimovič K., Das byzantinische Syntagma in 14 Titeln ohne Kommentare in altbulgarischer Übersetzung. Slavisch-griechisches, griechisch-slavisches und rückläufiges (slavisches) Wortregister, vol. I-II, Frankfurt am Main 2010 [= Forschungen zur Byzantinischen Rechtsgeschichte, 27].

Moroni G., Dizionario di erudizione storico-ecclesiastica da S. Pietro sino ai nostri giorni, vol. XLI, Venezia 1846.

Opuscula monophysitica Ioannis Philoponi, ed. A. ŠAndRa, Beirut 1930.

PÁstori-Kupán I., Theodoret of Cyrus, New York 1996 [= The Early Church Fathers].

RICHARD C.-L., Biblioteca sacra ovvero Dizionario universale delle scienze ecclesiastiche, vol. XVIII, Milano 1837.

Simeonov sbornik (po Svetoslavoviya prepis ot 1073 g.), vol. I, Izsledvaniya i tekst, Sofia 1991; vol. II, Rechnik-indeks, Sofia 1993; vol. III, Gratski izvori, Sofia 2015.

SREZnevskij I.I., Obozrenie drevnih russkih spiskov Kormchey knigi, Sankt-Peterburg 1897.

Supplemento al Dizionario Tecnico-Etimologico-Filologico, ed. M.A. Marchi, Milano 1841.

Theodoretus Cyrensis, Historia ecclesiastica, [in:] Patrologiae cursus completus, Series graeca, vol. LXXXII, ed. J.-P. Migne, Paris 1864, col. 881-1280.

Theodoretus, Historia ecclesiastica, http://www.documentacatholicaomnia.eu/03d/0393-0457, _Theodoretus,_Historia_Ecclesiastica,_EN.pdf

Tvoreniya svyatyh ottsev, Tvoreniya sv. Epifaniya Kiprskago, vol. XLII, pars 1, 1863; vol. XLIV, pars 2, 1864; pars 3, 1872; vol. XLVIII, pars 4, 1880; vol. V, pars 5, 1882. 
Undol'sKiY V.M., Opisanie slavyanskih rukopisey Moskovskoy partiarshey biblioteki, Moskva 1867 [= Чтения в Императорском обществе истории и древностей российских при Московском университете / Chteniya v Imperatorskom obshtestve istorii i drevnostey rossiyskih pri Moskovskom universitete, 2.3].

Vacant A., Dictionnaire de Théologie Catholique, vol. I, Paris 1909.

\section{Secondary Literature}

Averina S.A., Slozhnye slova v yazyke XII v., [in:] Drevnerusskiy yazyk domongol'skoy pory. Mezhvuzovskiy sbornik, ed. V.V. Kolesov, Leningrad 1991, p. 163-173.

Bianchi-Giovini A., Sulla Storia Universale di Cesare Cantù, Milano 1846.

DuJčev I., I bogomili nei paesi slavi e la loro storia, [in:] Medioevo bizantino-slavo, vol. I, Saggi di storia politica e culturale, Roma 1965, p. 251-282.

Lourié B., John Philoponus, On the Bodily Resurrection, "Scrinium" 9, 2013, p. 79-88.

MacCoull L.S.B., John Philoponus: Egyptian Exegete, Ecclesiastical Politician, [in:] Coptic Perspectives on Late Antiquity, Aldershot 1993, p. 211-220.

Mакsıмоvicн K.A., Drevnerusskaya Efremovskaya kormchaya XII v.: lokalizatsiya perevoda v svyazi s istoriey teksta, [in:] Lingvisticheskoe istochnikovedenie i istoriya russkogo yazyka, ed. A.M. MoLDovan, A.A. Pletneva, Moskva 2006, p. 102-113.

Mondin B., Storia della Teologia. Epoca patristica, vol. I, Bologna 1996.

Овоlensky D., The Bogomils. A Study in Balkan Neo-Manichaeism, Cambridge 1948 [repr. New York 1978].

Pichradze A.A., Perevodcheskaya deyatel' nost' v domongol'skoy Rusi. Lingvisticheskiy aspekt. Rukopis'nye pamyatniki Drevney Rusi, Moskva 2011.

Rigo A., Messalianismo = Bogomilismo. Un'equazione dell'eresiologia medievale bizantina, "Orientalia Christiana Periodica” 56, 1990, p. 53-82.

Rigo A., Monaci esicasti e monaci bogomili. Le accuse di Messalianismo e Bogomilismo rivolte agli esicasti ed il problema dei rapporti tra Esicasmo e Bogomilismo, Firenze 1989 [= Orientalia Venetiana, 2].

Turilov A.A., Florya B.N., Hristianskaya literatura u slavyan v seredine X - seredine XI v. i mezhslavyanskie kulturnye svyazi, [in:] Hristianstvo v stranah Vostochnoy, Yugo-Vostochnoy i TsentraI'noy Evropy na poroge vtorogo tysyachiletiya, ed. B.N. Florya, Moskva 2002, p. 398-459.

Velinova V., Srednobalgarskiyat prevod na Hronikata na Konstantin Manasiy i negoviyat literaturen kontekst, Sofia 2013.

Vyalkina L.V., Slozhnye slova $v$ drevnerusskom yazyke $v$ ih otnosheniy $k$ yazyku grecheskogo originala (na materiale Efremovskoy kormchey), [in:] Issledovaniya po istoricheskoy leksikologii drevnerusskogo yazyka, Moskva 1964, p. 94-118.

\footnotetext{
Abstract. The Panarion treatise is a dogmatic and polemical writing that earned Epiphanius his well-deserved reputation of a zealous defender of the Orthodox faith and a "hunter of heresies". Its list of heresies was translated into Church Slavonic during the $1^{\text {st }}$ Bulgarian Empire at the time of tsar Symeon and quickly spread throughout the Slavic-Orthodox world. It is a part of the oldest Slavonic version of Syntagma of XIV titles without any commentary (Syntagma XIV titulorum sine scholiis),
} 
called Efremovskaya Kormchaya. It is a monumental compendium of the centenary heresiological literature, and is the most complete treatise on heresies that the age of the Fathers left us. The paper presents a description of the three books and seven volumes of the Panarion with a list of eighty heresies, sects and schisms - twenty heresies before the incarnation of Christ and sixty of Christian times. Within the work attributed to Epiphanius, a chapter of the Ecclesiastical History of Theodoret of Cyrus and two other chapters of the theological-philosophical work Arbiter or Umpire by Joannes Philoponus have been identified. A number of 103 heresies was revealed, all of them ascribed to Epiphanius. It is presented as a preliminary study of 140 terms used by an anonymous Slavic translator. To the various lexemes, two different criteria have been applied: grammatical and semantic. The research determines 15 ethnonyms and eponyms, 60 anthroponyms formed on the names of the heresiarchs, 30 calques from Greek and 35 compounds. Among the latter, two distinct groups have been distinguished: structural calques, exactly corresponding to the Greek models, and "neologisms", formally independent of the Greek formations. Adaptation to the original Bulgarian linguistic system was achieved by the translator (or the editor) by using interpretative supplements, i.e. glosses. It is assumed that the translator's primary objective was to remain as faithful as possible to the Greek original. It turns out that the translator showed excellent knowledge of the complex Greek models of word formation and exceptional skills in adapting them to the Palaeoslavic linguistic system. The compound lexemes were created for stylistic reasons and are a result of a specific translation technique.

Keywords: Efremovskaya Kormchaya, Epiphanios of Salamis, Panarion, heresies, word formation, calques, compounds

Tatiana Lekova

"L'Orientale" University of Naples Via Duomo 219, Palazzo Santa Maria Porta Coeli Napoli 80138, Italy tlekova@yahoo.it 